\title{
Antimicrobial Susceptibility Pattern and Detection of Extended-Spectrum Beta-Lactamase (blaCTX-M) Gene in Escherichia coli from Urinary Tract Infections at the University Teaching Hospital in Lusaka, Zambia
}

Emmanuel Chirwa 1,2, Georgina Mulundu², Kunda Ndashe ${ }^{3,4}, K^{1}$ alo Kanongesha ${ }^{5}$, Wezi Kachinda ${ }^{1,2}$, Kaziwe Simpokolwe ${ }^{1,2}$, Bernard Mudenda Hang'ombe ${ }^{4}$

1. Department of Biology, Faculty of Premedical Sciences, Lusaka Apex Medical University, Lusaka, Zambia.

2. Department of Pathology and Microbiology, School of Medicine, The University of Zambia, Lusaka, Zambia

3. Department of Environmental Health, Faculty of Health Science, Lusaka Apex Medical University, Lusaka, Zambia.

4. Department of Para clinical Studies, School of Veterinary Medicine, The University of Zambia, Lusaka, Zambia.

5. Urology Department, University Teaching Hospital, Lusaka, Zambia. 
medRxiv preprint doi: https://doi.org/10.1101/2020.05.16.20103705; this version posted May 18, 2020. The copyright holder for this preprint (which was not certified by peer review) is the author/funder, who has granted medRxiv a license to display the preprint in perpetuity.

\section{ABSTRACT}

Background: Urinary tract infections caused by Extended Spectrum BetaLactamase producing Escherichia coli are increasing globally and yet treatment still remains a challenge due to antibiotic resistance of the causative agent.

Objectives: The aim of the study was to determine the antimicrobial susceptibility pattern and detect the presence of blaCTX-M gene in Escherichia coli isolated from urinary tract infection patients at the University Teaching Hospital, Lusaka, Zambia.

Methodology: This was a cross sectional study that involved collection of urine samples from patients who were diagnosed with urinary tract infections. The samples were cultured on MacConkey agar complemented with cefotaxime and Polymerase Chain Reaction was performed to confirm the Extended Spectrum BetaLactamase producers by detecting the CTX-M gene. Antimicrobial susceptibility tests were conducted using standard methods.

Results: A total of 327 urine samples were cultured and $15(4.6 \%)$ of these samples were positive ESBL producers. The isolates showed complete resistance to ampicillin and cotrimoxazole.

Conclusion: Multi drug resistant Extended Spectrum Beta-Lactamase producing Escherichia coli was detected in $4.6 \%$ of UTI patients at the University Teaching Hospital.

Key words: Escherichia coli, Extended Spectrum Beta Lactamase, Urinary tract infection 
medRxiv preprint doi: https://doi.org/10.1101/2020.05.16.20103705; this version posted May 18, 2020. The copyright holder for this preprint (which was not certified by peer review) is the author/funder, who has granted medRxiv a license to display the preprint in perpetuity.

\section{INTRODUCTION}

Urinary tract infections (UTIs) are some of the most common bacterial infections affecting 150 million people each year globally (Stamm and Norrby, 2001). In Africa, two studies reported that the prevalence of UTIs was $0.7 \%$ and $4.5 \%$ in Algeria and Senegal, respectively, (Atif et al., 2006; Dia et al., 2008), while a retrospective study from Nigeria reported a frequency of $12.3 \%$ (Jombo et al., 2006). A study conducted in Zambia reported a prevalence of $33 \%$ of UTIs among paediatrics at the University Teaching Hospital in Lusaka district [5].

The spectrum of bacteria causing UTIs include Escherichia coli (E. Coli), Citrobacter spp, Enterobacter aerogenes, Pseudomonas aeruginosa, Proteus vulgaris, and Klebsiella spp, whereas Staphylococcus spp, and Salmonella spp. are found rarely (Abujnah et al., 2015; Davies and Davies, 2010). Chisanga and colleagues reported that E. coli, Klebsiella spp, Proteus spp and Staphylococcus saprophyticus were isolated from patients with UTIs in Zambia (Chisanga et al., 2017). Therefore E. coli and Klebsiella spp remain the commonest uropathogens that cause severe infections. These bacteria have the ability to produce Extended Spectrum BetaLactamase (ESBL), which are plasmid-borne enzymes that confer multiple drug resistance hence making UTIs difficult to treat (Lautenbach et al., 2001; Rupp and Fey, 2003). The ESBL producing bacteria have shown resistance to fluoroquinolones, aminoglycosides, and fourth-generation cephalosporins, (Kariuki et al., 2007; Lautenbach et al., 2001).

Extended Spectrum Beta-Lactamases mainly include TEM, SHV, CTX-M, VEB, and GES enzymes (Bonnet, 2004) and the highest number of variants corresponds to the CTX-M family (Cantón and Coque, 2006). CTX-M beta lactamases produced by Escherichia coli have emerged worldwide as an important cause of infections and this has been described as the "the CTX-M pandemic" (Cantón and Coque, 2006). During the past two decades these enzymes have been reported as the commonest 
medRxiv preprint doi: https://doi.org/10.1101/2020.05.16.20103705; this version posted May 18, 2020. The copyright holder for this preprint (which was not certified by peer review) is the author/funder, who has granted medRxiv a license to display the preprint in perpetuity.

type of ESBL found in most areas of the world (Bonnet, 2004). In Africa, E .coli producing CTX-M beta lactamase have been identified in several counties which include Algeria, Tunisia, Cameroon, Tanzania and the Central African Republic(Bercion et al., 2009; Blomberg et al., 2005; Gangoué-Piéboji et al., 2005; Ramdani-Bouguessa et al., 2006; Sallem et al., 2012). The proportion of ESBLproducing bacteria causing common infections in all regions of the world is high, making antibiotic resistance due to ESBL being a major global public health problem.

This study was undertaken in view of "the CTX-M pandemic" globally as reported by other researchers. The aim of the study was to determine the antimicrobial susceptibility pattern and detect the presence of blaCTX-M gene in $E$ coli isolated from UTI patients at the University Teaching Hospital, Lusaka, Zambia.

\section{MATERIALS AND METHODS}

Study Area

The study was conducted at the University Teaching Hospital (UTH), Lusaka, Zambia. The urine samples were collected from patients that reported to Urology, outpatient and Maternity departments and were diagnosed with UTI.

\section{Study population}

The urine samples of 327 patients, both in patients and out patients who attended the urology department of UTH and had evidence of UTI determined by treating physicians were included in the study. Patients on antibiotic therapy were excluded from the study. Ethical clearance was obtained from the University of Zambia Biomedical Research Ethics Committee (Ref. 007-01-17) and a written consent and assent form was sought from each patient or bed-sider. 
medRxiv preprint doi: https://doi.org/10.1101/2020.05.16.20103705; this version posted May 18, 2020. The copyright holder for this preprint (which was not certified by peer review) is the author/funder, who has granted medRxiv a license to display the preprint in perpetuity.

\section{Sample Collection}

Clean catch midstream urine was collected from each patient into $20 \mathrm{~mL}$ sterile universal container. The specimen were labelled and transported to the bacteriology laboratory at the University Teaching Hospital, with 6 hours of collection. In each container boric acid $(0.1 \mathrm{~g} / 10 \mathrm{ml}$ of urine) was added to prevent the growth of bacteria in the urine sample.

Isolation of ESBL Escherichia coli

Initial screening was conducted by inoculating each sample on MacConkey agar (Oxoid, UK) supplemented with cefotaxime at a screening concentration of $2 \mu \mathrm{g} / \mathrm{ml}$ and incubated at $37^{\circ} \mathrm{C}$ for 24 hours. The positive cultures were then sub cultured on MacConkey agar (Oxoid, UK) and pure colonies were then obtained. Identification of bacterial isolates was done on the basis of their cultural and biochemical characteristics.

\section{Molecular detection of blaCTX-M gene}

For detection of blaCTX-M gene, the isolates were cultured in Brain Heart Infusion, (Himedia, India) at $37^{\circ} \mathrm{C}$ for 18 hours. After incubation, $1 \mathrm{ml}$ of bacterial suspension was centrifuged at $5800 \mathrm{xg}$ for 5 minutes, thereafter, the supernatant was discarded. The remaining cell pellet was washed with $500 \mu$ l of normal saline, centrifuged at

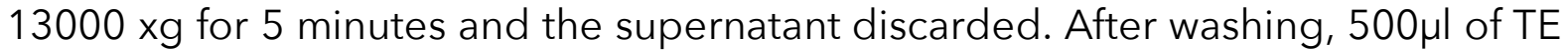
buffer ( $\mathrm{pH}$ 8.0) was added to the cell pellet and then heat treated until boiling, then immediately transferred to ice for 10 minutes. The cell debris was removed after centrifuging at $13000 \mathrm{xg}$ for 5 minutes, while the supernatant was transferred into a new microfuge tube and stored at $-20^{\circ} \mathrm{C}$ until use (Paterson and Bonomo, 2005).

The master mix per reaction tube was made with $5 \mu$ l of Phusion Flash, $2 \mu l$ sterile water, $1 \mu$ of reverse primer, $1 \mu$ l of forward primer and $1 \mu l$ of DNA template, giving 
medRxiv preprint doi: https://doi.org/10.1101/2020.05.16.20103705; this version posted May 18, 2020. The copyright holder for this preprint

(which was not certified by peer review) is the author/funder, who has granted medRxiv a license to display the preprint in perpetuity.

All rights reserved. No reuse allowed without permission.

total volume of $10 \mu \mathrm{l}$ per reaction tube, which was mixed using a vortex mixer. The PCR primers used for the detection of blaCTX-M are indicated in Table 1. The PCR conditions were set as $98^{\circ} \mathrm{C}$ for 30 seconds, $98^{\circ} \mathrm{C}$ for 0 seconds, $60^{\circ} \mathrm{C}$ for 5 seconds (35 cycles), $72^{\circ} \mathrm{C}$ for 15 seconds, $72^{\circ} \mathrm{C}$ for 2 minutes, and holding at $4^{\circ} \mathrm{C}$ infinitely. After PCR, the products were visualized on a trans-illuminator machine following staining with ethidium bromide [20].

\section{Antibiotic Susceptibility Testing}

The blaCTX-M positive isolates were tested for antimicrobial susceptibility testing by the standard Kirby Bauer's disc diffusion method. Standard inoculums adjusted to 0.5 McFarland was swabbed on Mueller Hinton agar and was allowed to soak for 2 to 5 minutes. After that antibiotic disks were placed on the surface of media and pressed gently. Mueller Hinton agar plates were then incubated at $37 \circ \mathrm{C}$ for $24 \mathrm{~h}$. After $24 \mathrm{~h}$ the inhibition zones were measured and interpreted by the recommendations of clinical and laboratory standards [21]. The following standard antibiotic discs were used for the isolates, Ampicillin (A), Cotrimoxazole (Co), Tetracycline (TE), Gentamycin (G), Nitrofurantoin (NIT), Chloramphenicol (C), Nalidixic acid (NA), Cephotaxin (CTX), Norfloxacin (NX) and Ciprofloxacin (CIP).

\section{RESULTS}

The overall prevalence of ESBL E. coli in UTI patients was found to be $4.6 \%$ (15/327), this was confirmed by culturing urine samples on MacConkey agar supplemented with cefotaxime. Of the 15 ESBL E. coli positive samples, blaCTX-M gene was detected in 14 samples [figure 1].

Antibiogram by Kirby and Bauer's method was carried out for all the 15 identified isolates of E. coli and a total of 10 antibiotics were used. The percentage of resistance clearly indicates that $\mathrm{ESBL}$ producers are totally not responding to 
medRxiv preprint doi: https://doi.org/10.1101/2020.05.16.20103705; this version posted May 18, 2020. The copyright holder for this preprint (which was not certified by peer review) is the author/funder, who has granted medRxiv a license to display the preprint in perpetuity.

Ampicillin (100\%), Cotrimoxazole (100\%), Cephotaxin (87\%), Tetracycline (53\%), Nalidixic acid (47\%), Norfloxacin (47\%), Ciprofloxacin (47\%), Chloramphenicol (40\%), Gentamycin (13\%) and Nitrofurantoin (0\%) [Figure 2].

\section{DISCUSSION}

The ESBL E. coli proportion estimate of patients clinically diagnosed with UTI in this study was $4.6 \%$. The results of this study indicate lower estimates than those reported in other African countries such as Tunisia (7.3\%), Cameroon (12\%), Algeria (20\%) and Tanzania (25\%) (Blomberg et al., 2005; Gangoué-Piéboji et al., 2005; Ramdani-Bouguessa et al., 2006; Sallem et al., 2012). Furthermore, in resource-rich countries such as Germany the average ESBL proportion estimates reported in a nationwide hospital survey for 2012 were between 10 to 15 \% (Leistner et al., 2015). In the same year 2012, in United States of America the ESBL proportion estimates ranged between 4 to $12 \%$ (Castanheira et al., 2014). It is important to note that the present study focused on both nosocomial and community acquired infections while the other studies were concerned with nosocomial infections only. The differences in ESBL proportion estimates maybe attributed to variations in populations surveyed, difference in clinical diagnostic methods for UTIs, or by the levels of antibiotic use in the community.

In the present study, genes coding for CTX-M were detected in 93\% of the samples that were positive for ESBL E. coli on culture. Currently, CTX-M enzymes include more than 80 different enzymes that are clustered into 5 groups based on their amino acid sequences and the include CTX-M-1, -2, -8, -9 and -25 (Paterson and Bonomo, 2005). However, sequencing was not done to discriminate between the 5 CTX-M groups. The detection of CTX-M gene in $4.3 \%$ and $93 \%$ of clinically diagnosed UTI cases and ESBLE. coli isolates, respectively, is indication of growing problem in UTIs being caused by drug resistant bacteria. The study collected urine 
medRxiv preprint doi: https://doi.org/10.1101/2020.05.16.20103705; this version posted May 18, 2020. The copyright holder for this preprint (which was not certified by peer review) is the author/funder, who has granted medRxiv a license to display the preprint in perpetuity. All rights reserved. No reuse allowed without permission.

samples from both in-patients and out-patients at the University Teaching Hospital, therefore indicating the presence of CTX-M gene in both nosocomial and community UTI infections. The spread of CTX-M gene in the community has already been described through studies conducted in industrialized countries such as Canada (Pitout et al., 2004), France (Arpin et al., 2003), and the United Kingdom (Woodford et al., 2004). Although not determined in this study, risk factors for acquiring community-onset infection due of CTX-M producing E. coli include repeat UTIs, underlying renal pathologies, previous hospitalisation, nursing home residents, diabetes mellitus, underlying liver pathology and international travel (Laupland et al., 2008; Paterson and Bonomo, 2005; Rodríguez-Baño et al., 2008).

Multidrug resistance was recorded in all the ESBL E. coli isolates in this study. The resistance was very high to Ampicillin (100\%), Cotrimoxazole (100\%) and Cephotaxin (87\%). The resistance patterns were extended even to non-beta-lactam antibiotics such as nalidixic acid (47\%), tetracycline (53\%), norfloxacin (47\%), ciprofloxacin (47\%) and chloramphenicol (40\%). Quinolones have been used to treat complicated UTIs associated with ESBL-producing organisms without in vitro resistance to the drug (Paterson and Bonomo, 2005). However, recent studies associate ESBL production with fluoroquinolone resistance (Rupp and Fey, 2003), and in this study, resistance was high for ciprofloxacin (47\%), norfloxacin (47\%) and nalidixic acid (47\%). The resistance to both beta-lactam antibiotics and other classes of antibiotics in this study suggests the presence of other antimicrobial resistance genes in E. coli isolates in addition to ESBL genes, leading to multidrug resistance (Paterson, 2006; Rao et al., 2014). The observed multidrug resistance in ESBL producing isolates has an implication on treatment, limiting the available options for curative therapy for UTIs. Globally, there has been increased resistance to commonly used antibiotics. Self-medication and lack of completion of antibiotic 
medRxiv preprint doi: https://doi.org/10.1101/2020.05.16.20103705; this version posted May 18, 2020. The copyright holder for this preprint

(which was not certified by peer review) is the author/funder, who has granted medRxiv a license to display the preprint in perpetuity.

All rights reserved. No reuse allowed without permission.

treatment has been recognised as some of the contributing factors to antibiotic resistance (Mshana et al., 2013).

\section{CONCLUSION}

The prevalence of extended spectrum beta lactamase -producing Escherichia coli among urinary tract infections at University Teaching Hospital, Zambia are $4.5 \%$. The CTX-M gene was detected in 93\% of ESBL E. coli isolates. Furthermore, ESBL E. coli isolates showed multi drug resistance

With complete resistance to ampicillin and Cotrimoxazole but was susceptible to nitrofurantoin.

\section{ACKNOWLEDGEMENT}

We would like to recognize that this was a study undertaken by Emmanuel Chirwa as partial fulfilment for Master of Science Medical Microbiology of the University of Zambia. We wish to express our gratitude to the staff at the University Teaching Hospital, Bacteriology Laboratory and School of Veterinary Medicine, Bacteriology and Molecular Diagnostics Laboratories for technical help rendered during bench work sessions of the research. Finally, we are indebted to the patients of University Teaching Hospital that allowed us to collect samples to conduct the research, to them we say thank you. 
medRxiv preprint doi: https://doi.org/10.1101/2020.05.16.20103705; this version posted May 18, 2020. The copyright holder for this preprint (which was not certified by peer review) is the author/funder, who has granted medRxiv a license to display the preprint in perpetuity.

\section{REFERENCES}

Abujnah, A.A., Zorgani, A., Sabri, M.A., El-Mohammady, H., Khalek, R.A., Ghenghesh, K.S., 2015. Multidrug resistance and extended-spectrum $\beta$ lactamases genes among0 Escherichia coli from patients with urinary tract infections in Northwestern Libya. Libyan J. Med. 10.

Arpin, C., Dubois, V., Coulange, L., André, C., Fischer, I., Noury, P., Grobost, F., Brochet, J.-P., Jullin, J., Dutilh, B., 2003. Extended-spectrum $\beta$-lactamaseproducing Enterobacteriaceae in community and private health care centers. Antimicrob. Agents Chemother. 47, 3506-3514.

Atif, M.-L., Bezzaoucha, A., Mesbah, S., Djellato, S., Boubechou, N., Bellouni, R., 2006. Évolution de la prévalence des infections nosocomiales dans un centre hospitalier universitaire en Algérie (2001 à 2005). Médecine Mal. Infect. 36, 423-428.

Bercion, R., Mossoro-Kpinde, D., Manirakiza, A., Le Faou, A., 2009. Increasing prevalence of antimicrobial resistance among Enterobacteriaceae uropathogens in Bangui, Central African Republic. J. Infect. Dev. Ctries. 3, 187-190.

Blomberg, B., Jureen, R., Manji, K.P., Tamim, B.S., Mwakagile, D.S., Urassa, W.K., Fataki, M., Msangi, V., Tellevik, M.G., Maselle, S.Y., 2005. High rate of fatal cases of pediatric septicemia caused by gram-negative bacteria with extended-spectrum beta-lactamases in Dar es Salaam, Tanzania. J. Clin. Microbiol. 43, 745-749.

Bonnet, R., 2004. Growing group of extended-spectrum $\beta$-lactamases: the CTX-M enzymes. Antimicrob. Agents Chemother. 48, 1-14.

Cantón, R., Coque, T.M., 2006. The CTX-M $\beta$-lactamase pandemic. Curr. Opin. Microbiol. 9, 466-475.

Castanheira, M., Farrell, S.E., Krause, K.M., Jones, R.N., Sader, H.S., 2014. Contemporary diversity of $\beta$-lactamases among Enterobacteriaceae in the nine US census regions and ceftazidime-avibactam activity tested against isolates producing the most prevalent $\beta$-lactamase groups. Antimicrob. Agents Chemother. 58, 833-838.

Chisanga, J., Mazaba, M.L., Mufunda, J., Besa, C., Kapambwe-muchemwa, M.C., Siziya, S., 2017. Antimicrobial susceptibility patterns and their correlate for urinary tract infection pathogens at Kitwe Central Hospital, Zambia. Health Press.

Davies, J., Davies, D., 2010. Origins and evolution of antibiotic resistance. Microbiol Mol Biol Rev 74, 417-433.

Dia, N.M., Ka, R., Dieng, C., Diagne, R., Dia, M.L., Fortes, L., Diop, B.M., Sow, A.l., Sow, P.S., 2008. Prevalence of nosocomial infections in a university hospital (Dakar, Senegal). Med. Mal. Infect. 38, 270-274.

Gangoué-Piéboji, J., Bedenic, B., Koulla-Shiro, S., Randegger, C., Adiogo, D., Ngassam, P., Ndumbe, P., Hächler, H., 2005. Extended-spectrum- $\beta$ - 
medRxiv preprint doi: https://doi.org/10.1101/2020.05.16.20103705; this version posted May 18, 2020. The copyright holder for this preprint (which was not certified by peer review) is the author/funder, who has granted medRxiv a license to display the preprint in perpetuity. All rights reserved. No reuse allowed without permission.

lactamase-producing Enterobacteriaceae in Yaounde, Cameroon. J. Clin. Microbiol. 43, 3273-3277.

Jombo, G.T., Egah, D.Z., Banwat, E.B., Ayeni, J.A., 2006. Nosocomial and community acquired urinary tract infections at a teaching hospital in north central Nigeria: findings from a study of 12,458 urine samples. Niger. J. Med. J. Natl. Assoc. Resid. Dr. Niger. 15, 230-236.

Kariuki, S., Revathi, G., Corkill, J., Kiiru, J., Mwituria, J., Mirza, N., Hart, C.A., 2007. Escherichia coli from community-acquired urinary tract infections resistant to fluoroquinolones and extended-spectrum beta-lactams. J. Infect. Dev. Ctries. 1, 257-262.

Laupland, K.B., Church, D.L., Vidakovich, J., Mucenski, M., Pitout, J.D., 2008. Community-onset extended-spectrum $\beta$-lactamase (ESBL) producing Escherichia coli: importance of international travel. J. Infect. 57, 441-448.

Lautenbach, E., Patel, J.B., Bilker, W.B., Edelstein, P.H., Fishman, N.O., 2001. Extended-spectrum $\beta$-lactamase-producing Escherichia coli and Klebsiella pneumoniae: risk factors for infection and impact of resistance on outcomes. Clin. Infect. Dis. 32, 1162-1171.

Leistner, R., Schröder, C., Geffers, C., Breier, A.-C., Gastmeier, P., Behnke, M., 2015. Regional distribution of nosocomial infections due to ESBL-positive Enterobacteriaceae in Germany: data from the German National Reference Center for the Surveillance of Nosocomial Infections (KISS). Clin. Microbiol. Infect. 21, 255-e1.

Mshana, S.E., Matee, M., Rweyemamu, M., 2013. Antimicrobial resistance in human and animal pathogens in Zambia, Democratic Republic of Congo, Mozambique and Tanzania: an urgent need of a sustainable surveillance system. Ann. Clin. Microbiol. Antimicrob. 12, 28.

Paterson, D.L., 2006. Resistance in gram-negative bacteria: Enterobacteriaceae. Am. J. Infect. Control 34, S20-S28.

Paterson, D.L., Bonomo, R.A., 2005. Extended-spectrum $\beta$-lactamases: a clinical update. Clin. Microbiol. Rev. 18, 657-686.

Pitout, J.D., Hanson, N.D., Church, D.L., Laupland, K.B., 2004. Population-Based Laboratory Surveillance for Escherichia coli-Producing Extended-Spectrum $\beta$-Lactamases: Importance of Community Isolates with bla CTX-M Genes. Clin. Infect. Dis. 38, 1736-1741.

Ramdani-Bouguessa, N., Mendonça, N., Leitão, J., Ferreira, E., Tazir, M., Caniça, M., 2006. CTX-M-3 and CTX-M-15 extended-spectrum $\beta$-lactamases in isolates of Escherichia coli from a hospital in Algiers, Algeria. J. Clin. Microbiol. 44, 4584-4586.

Rao, L., Lv, L., Zeng, Z., Chen, S., He, D., Chen, X., Wu, C., Wang, Y., Yang, T., Wu, P., 2014. Increasing prevalence of extended-spectrum cephalosporinresistant Escherichia coli in food animals and the diversity of CTX-M genotypes during 2003-2012. Vet. Microbiol. 172, 534-541. 
medRxiv preprint doi: https://doi.org/10.1101/2020.05.16.20103705; this version posted May 18, 2020. The copyright holder for this preprint (which was not certified by peer review) is the author/funder, who has granted medRxiv a license to display the preprint in perpetuity. All rights reserved. No reuse allowed without permission.

Rodríguez-Baño, J., Alcalá, J.C., Cisneros, J.M., Grill, F., Oliver, A., Horcajada, J.P., Tórtola, T., Mirelis, B., Navarro, G., Cuenca, M., 2008. Community infections caused by extended-spectrum $\beta$-lactamase-producing Escherichia coli. Arch. Intern. Med. 168, 1897-1902.

Rupp, M.E., Fey, P.D., 2003. Extended spectrum $\beta$-lactamase (ESBL)-producing Enterobacteriaceae. Drugs 63, 353-365.

Sallem, R.B., Slama, K.B., Estepa, V., Jouini, A., Gharsa, H., Klibi, N., Sáenz, Y., RuizLarrea, F., Boudabous, A., Torres, C., 2012. Prevalence and characterisation of extended-spectrum beta-lactamase (ESBL)-producing Escherichia coli isolates in healthy volunteers in Tunisia. Eur. J. Clin. Microbiol. Infect. Dis. 31, 1511-1516.

Stamm, W.E., Norrby, S.R., 2001. Urinary tract infections: disease panorama and challenges. J. Infect. Dis. 183, S1-S4.

Woodford, N., Ward, M.E., Kaufmann, M.E., Turton, J., Fagan, E.J., James, D., Johnson, A.P., Pike, R., Warner, M., Cheasty, T., 2004. Community and hospital spread of Escherichia coli producing CTX-M extended-spectrum $\beta$ lactamases in the UK. J. Antimicrob. Chemother. 54, 735-743. 
medRxiv preprint doi: https://doi.org/10.1101/2020.05.16.20103705; this version posted May 18, 2020. The copyright holder for this preprint (which was not certified by peer review) is the author/funder, who has granted medRxiv a license to display the preprint in perpetuity.

\section{TABLES AND FIGURES}

Table 1: blaCTX-M Primers sequences

\begin{tabular}{|c|c|c|c|}
\hline Gene & Primer & Sequence & Expected amplicon size \\
\hline bla & blactX-M- $\mathrm{F}$ & 5' CGATGTGCAGTACCAGTAA 3' & 585 \\
\hline blactх-м & blactх-м- R & 5'-CCTCCCGCACGATGATC-3' & 585 \\
\hline
\end{tabular}

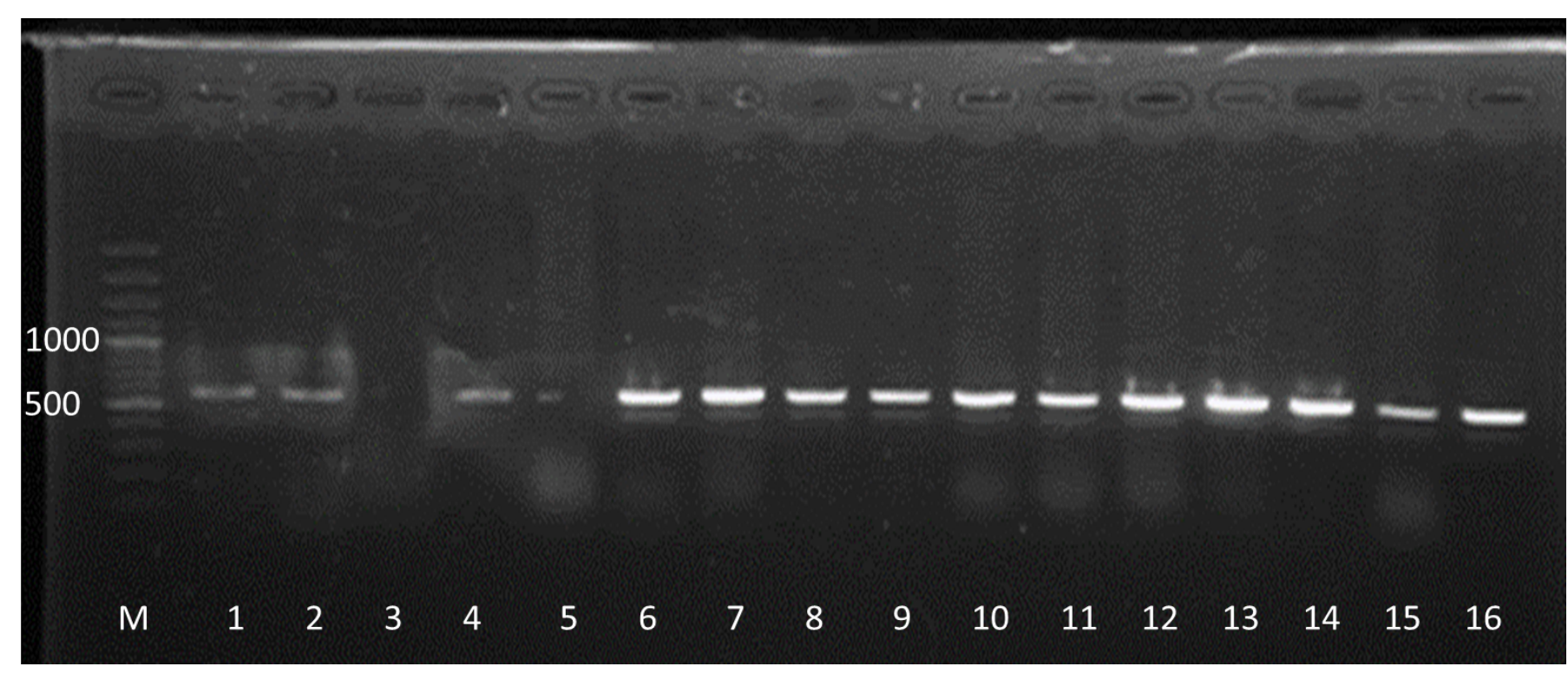

Figure 1: Gel electrophoresis picture for blaCTX-M gene in E coli from UTI. Lane M; DNA ladder (100bp), Lane 1 to 15 ESBL E coli positive samples, and Lane 16 the positive control. 
medRxiv preprint doi: https://doi.org/10.1101/2020.05.16.20103705; this version posted May 18, 2020. The copyright holder for this preprint (which was not certified by peer review) is the author/funder, who has granted medRxiv a license to display the preprint in perpetuity. All rights reserved. No reuse allowed without permission.

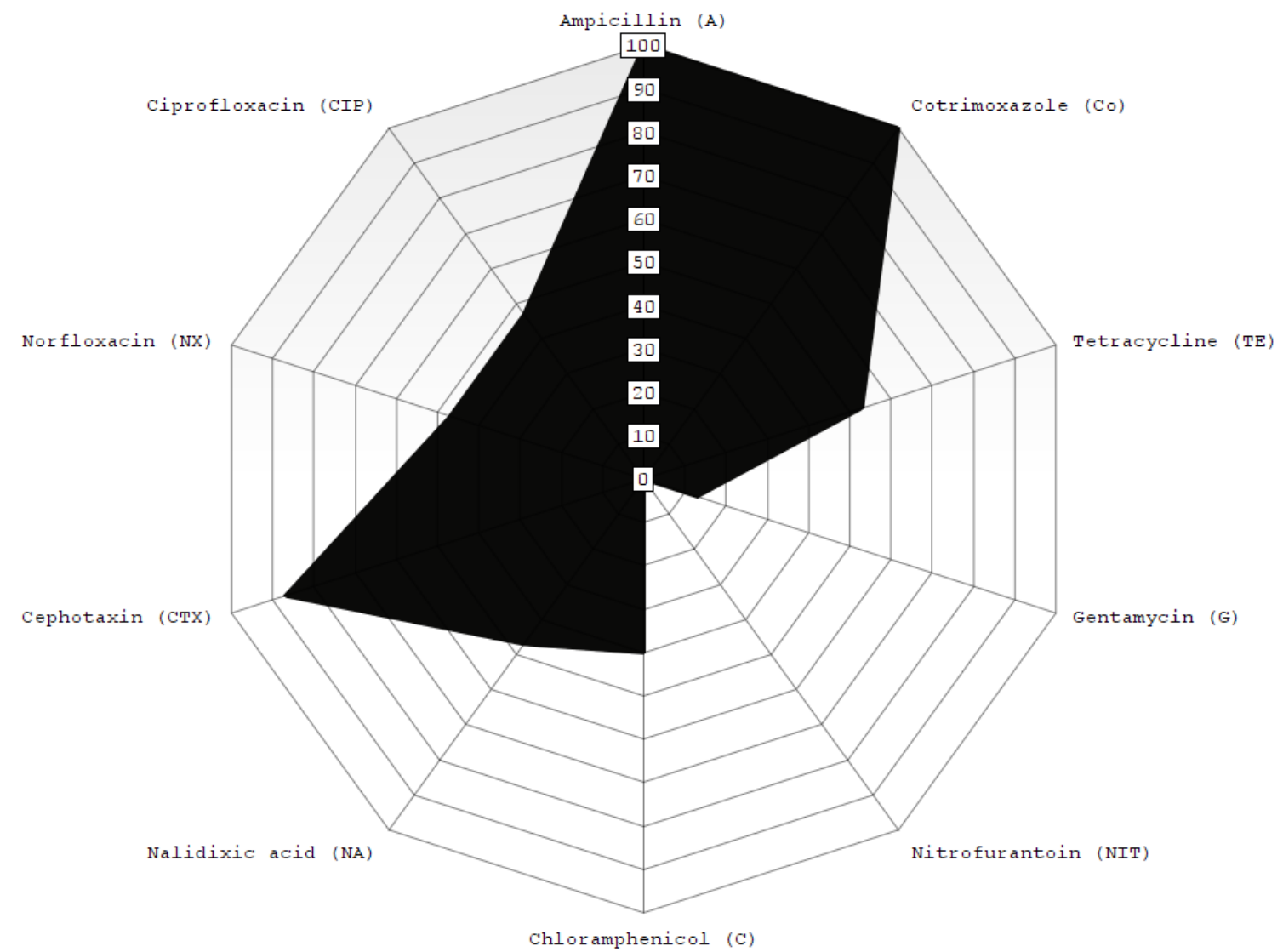

Figure 2: Antimicrobial resistance pattern of ESBL E. coli isolates detected with the CTX$M$ gene. The radar chart shows percentage resistance of the antibiotics used in the study, Ampicillin (100\%), Cotrimoxazole (100\%), Cephotaxin (87\%), Tetracycline (53\%), Nalidixic acid (47\%), Norfloxacin (47\%), Ciprofloxacin (47\%), Chloramphenicol (40\%), Gentamycin (13\%) and Nitrofurantoin (0\%). 